\title{
START-UPS AND INTERNATIONALISATION: THE CASE OF ROMANIA. PART 1. THEORETICAL OVERVIEW
}

\author{
Anamaria Diana Herte*, Daniel Badulescu \\ Department of Economic and Business and Doctoral School of Economics, Faculty of \\ Economic Sciences, University of Oradea, Oradea, Romania \\ dianaherte89@gmail.com \\ dbadulescu@uoradea.ro
}

\begin{abstract}
Within the general concept of companies, start-ups are, more practically than theoretically, a distinct category including the so-called newly born companies struggling for existence and confirmation. Although theories of start-ups are still emerging, it is known that these companies are set up to put in practice great ideas and they grow to reach the success desired by their founders. The definition is, from a strict scientific point of view, approximate and quite inconsistent, which is why the clarification of the category of start-ups can be done using contributions from the theories of management, organization, complexity, and entrepreneurship or life stages, while admitting that a clear picture of these entities is not yet available. Regardless of the multitude of perspectives, researchers and practitioners agree that growth is therefore an essential part in the development, consolidation and orientation of start-ups. It is therefore not uncommon to find that the vast majority of European start-ups are interested in internationalizing, or expanding their internationalization, in the immediate future, despite considerable difficulties and challenges, exacerbated by lack of experience and the market power of new companies. The situation of start-ups in Romania is a bit more complex and certainly not as enthusiastic - a series of constraints, objectives and subjective, make the expansion on new markets an option not as attractive for young small and medium Romanian companies.
\end{abstract}

Keywords: start-ups, internationalisation, European Union, Romania.

JEL classification: M13, O19, F23.

\section{Introduction}

The idea of starting and launching a business comes from a fairly common rationale (practically and theoretically acceptable), of the evolution of organizations and companies. The economy is full of experiences and evidence that organizations have a development that can be interpreted in terms of "biological", conception: birth, launch, development, maturity, decline and disappearance, but, surprisingly, there is a rather low emphasis in economic theory on the very early stages of a company, i.e. the launching phase, the startup. The lack of well-documented analyses on this early phase of companies is not without problems, controversies and challenges: Who are these entities?, What distinguishes them from other organizations?, How do they turn into actual companies?, Is there a specific moment which turns the start-up into a successful company or, respectively, one fated to a modest existence or even a rapid disappearance?

Start-ups have been identified and characterized by several important features. First of all, it is a high failure rate. Whether we are talking about new companies born to highlight an idea ("special" in the opinion of the founder), or we are talking about small companies set

* Corresponding author: Anamaria Diana Herte 
up without great ambitions, often for the simple survival of the founder and his family, most of these entities fail to survive and less than a third of them turn into companies (Rogers, 2009) (Badulescu \& Badulescu, 2014). Secondly, failure occurs for several reasons, such as lack of funding, team management problems, insufficient business knowledge, technological backwardness, which seem to be, if not exclusive, at least very specific to the start-up period. Third, there is in the (short) life of start-ups "a stage or a few critical moments, often difficult to explain (Van de Ven, et al., 1984) that makes the difference between resistance and disappearance, between survival and success. Finally, as a "moral reward" for crossing this difficult path, most of the start-ups which survive and succeed have a strong motivational effect on future entrepreneurial ideas and intentions, which often compete with the economic or innovative contribution of their own business, and we refer here to the socalled "success stories" (Salamzadeh, 2015).

\section{Start-ups: brief overview}

We can find five main approaches or perspectives from which start-ups can be understood. Incomplete if taken separately, together they can contribute to a better understanding of this phenomenon, and we refer here to: a. Managerial perspective, b. Organizational perspective, c. Entrepreneurial perspective, d. Life cycle theory and, finally, $d$. the perspective of complexity theory. Van de Ven et al. (1984) were among the first researchers to consider three main approaches to the study of start-ups, i.e. entrepreneurial, organizational and environmental, and argued for the need to understand these new businesses by integrating the three perspectives.

Organizational theories are quite poor in arguments about the evolution of start-ups, the start-up phase, and most existing theories and perspectives in the science of the organization are focused on answering questions about more sophisticated stages of the company's existence, such as the theory of organizational ecology (Scholz \& Reydon, 2009), organizational configurations (Miller, 2000), contingency theory (Tosi \& Slocum, 1984), resource dependence theory, uncertainty theory (Kamps \& Pólos, 1999) etc., as well as the specific contributions of Gartner (1985) and Katz and Gartner (1988) related to this category (Salamzadeh, 2015).

The management theory starts from its general principle, i.e. fulfilling of goals by coordinating the efforts of individuals and teams in order to achieve the proposed objectives. In fact, management theories have less to do with start-ups in an organizational sense, but more with those entities (individuals or teams) that coordinate their efforts towards common goals, and one of these goals could be setting up and launching a business. Management scholars are increasingly interested in studying start-ups (Salamzadeh, 2015), especially in the field of strategic management (Pettigrew, et al., 2001), small business governance (Ritchie \& Richardson, 2000), human resource management (Miles \& Rosenberg, 1983), team management (Kaiser \& Müller, 2013).

In the opinion of Van de Ven et al (1984), the entrepreneurial approach to start-ups is based on the characteristics of the founder and leader of a new organization, eclipsing, by pushing forward the features of the founding entrepreneur, certain aspects of the organization, the reasons and the way of resolving conflicts and crisis situations, the stages of growth. As Salamzadeh (2015) argues, entrepreneurial theories of start-ups fall into two categories: (1) theories at the macroeconomic level (Schumpeter, 1934), population ecology (Hannan \& Freeman, 1977), and (2) theories at micro and meso economic level (Vesper, 1990), (Bhave, 1994), (Lim, et al., 2008). Unlike organizational and management theories, this theory is much more focused and adapted to start-ups, at least for the fact that entrepreneurial theory deals with elements such as idea, creativity, innovation, development of new products or services, opportunities and others, which are actually the motivations and strengths of launching new companies. Moreover, some of the motivations and entrepreneurial resilience 
are closely related to going through the early, often difficult stages of any business or organization. Secondly, the transformation of the idea into a business is a central point of entrepreneurial theory, and the launch and the first stages of a start-up (legal formalities, risk management, evaluation and exploitation of opportunities, team building) are the "vehicle" through this transformation of the idea into a functional business can be achieved. Researchers also commonly use "organizational life cycle theory" to investigate the problem of developing start-ups. It presumes organizational growth as a consistent and predictable process, similar to the life cycle of an individual (or of a known biological entity), i.e. birth, maturity, aging and death. The basic argument of this theory is constructed as follows: the process of organizational growth consists of different stages, and an organization faces different problems at each stage. Therefore, an organization must possess different management skills, make different decisions and have a structure adapted to each stage (Adizes, 1989), (Greiner, 1972), (Kazanjian, 1988). In terms of the number of stages identified, theories are beginning to differ - from a simpler model of the three stages such as Smith et al. (1985) or Bhave (1994), up to the four-step model (Hanks \& Watson, 1993), fivestep model (Greiner, 1972), (Galbraith, 1982), and up to the ten-step model (Block \& MacMillan, 1985), (Adizes, 1989).

Despite the differences between the different life cycle models, their promoters usually consider that the growth and development of enterprises is a progressive and linear process and that all enterprises have to face certain key problems at each stage (Kaulio, 2003), (Kazanjian, 1988). Because entrepreneurs must overcome these problems before their business can enter the next stage of development, this theoretical perspective assumes that the development of the start-up is predictable and that entrepreneurs can plan management activities and adjust the organizational structure over time.

Accepting the existence of stages and moments in the "life of an enterprise", but partially contesting their content and succession, the complexity theory starts from the idea that the development of a start-up is dynamic, non-linear and unpredictable. Moreover, since the development of a start-up must begin with an initial event, immediately after the occurrence of this event, the development of the start-up is in a dynamic state of co-evolution with management, with the subjectivity of entrepreneurial decisions and it never reaches the kind of equilibrium observed in biological evolution. In other words, the development of a start-up can be seen as the attempt to "create order", and the use of complexity theory to study the launch and development of a start-up allows us to observe how each start-up constantly creates new orders in the environment (Tsai \& Lan, 2006) to determine the company to continuously adapt to a system, marked by "continuous change". Life cycle theory concerns the development of a start-up from a relatively holistic point of view, being particularly concerned with changes in the structure of the organization from its birth to its death (Katz \& Gartner, 1988). Complexity theory is partially validated by statistical data - over $30 \%-40 \%$ of enterprises do not have a process of progressive and linear growth assumed by life cycle theory (Slevin \& Covin, 1998), (Tsai \& Lan, 2006), and the development a new start-up is subject to various phenomena, non-homogeneous, dynamic and complex, difficult to integrate into the schematics of some stages (regardless of their number) as they are proposed in the theories of the life cycle of start-ups. One of the explanations probably comes from the fact that the logic of cycle theories is, at the same time, its weakness - life cycle theory assumes that the environment is predictable, one stage contains the germs of the next stage and that, therefore, change, breaking rhythm, return, alternation, shock are "exceptions". In contrast, in complexity theory the course of a firm is individual, organizations are dissipative structures in a state of imbalance and it is assumed that (unpredictable) change of environment is a rule, not an exception (Tsai \& Lan, 2006). All these approaches also show, indirectly, that start-ups are not simple entities, small variations of future large 
organizations, but are diversified and have a complex nature, specifically marking a certain stage of life of companies.

\section{Start-ups and the challenge of internationalization}

The internationalization of start-ups is a specific theme of this group of companies, probably, from our point of view, a little overestimated or often presented in a favourable light, as intrinsic in the development of this type of business. Marked by inherent problems (Badulescu, 2013), such as (i) financial challenges and constraints, (ii) lack of qualified human resources (or unwilling to enter an incipient, insecure business); (iii) support mechanisms and immature entrepreneurial ecosystem, (iv) low attention paid to environmental elements that can be easily transformed from opportunities into risks, it is hard to believe that most start-ups are well equipped to deal with these problems multiplicated on various markets, in an international context.

\subsection{Development and internationalization of start-ups: the European profile}

However, there is a certain category of start-ups, the so-called born global, which means that they operate across borders and, in some cases, they open an office in several countries since the beginning of the first operations. Growth is a crucial part in targeting start-ups and therefore $88.0 \%$ of start-ups participating in surveys within the European Union (Steigertahl \& Mauer, 2018) (Bormans, et al., 2020) stated that they intend to go international, or increase their degree of internationalization in the next 12 months.

Most European start-ups expand first into the European Union and usually start with neighbouring countries, before moving to wider international markets - $77 \%$ of participants reported internationalization plans in the EU over the next 12 months, and about 36\% want to do it outside the EU (especially in North America, followed by Asia), $26 \%$ in the EU and outside the EU, and $11 \%$ have no such intention.

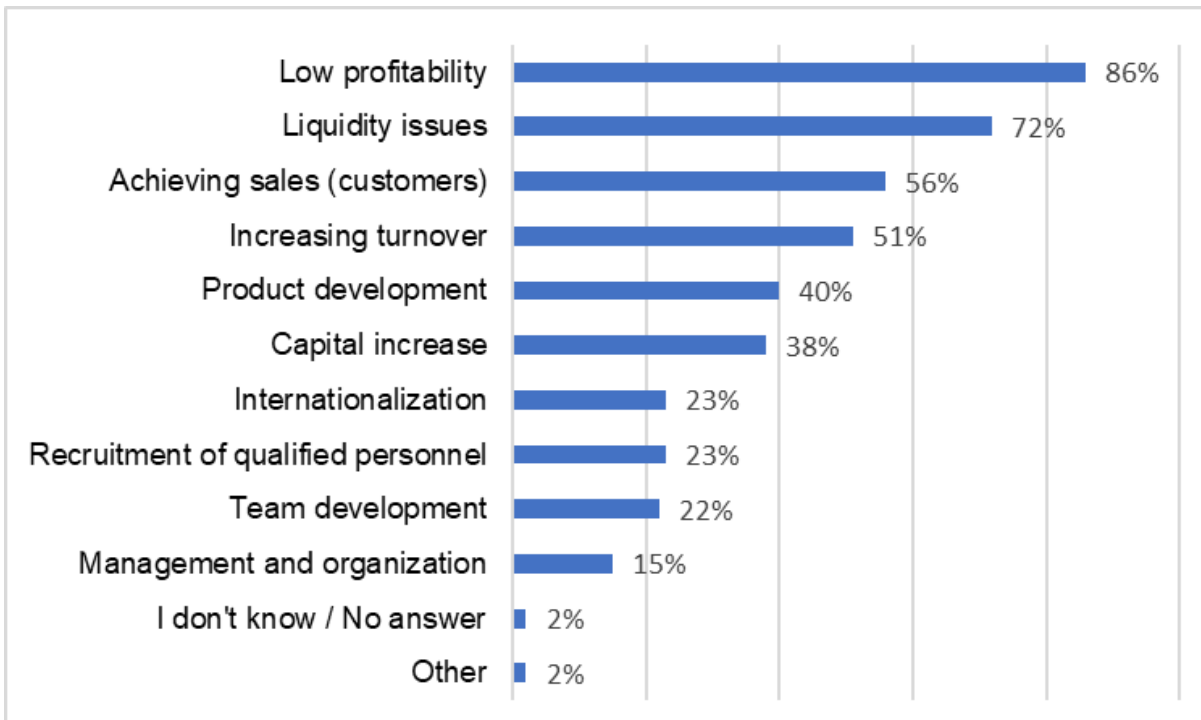

Figure 1: Challenges faced by start-ups in developing and internationalizing their businesses

Source: (Bormans, et al., 2020), (Steigertahl \& Mauer, 2018). 
Growing across borders is, however, difficult, and the founders face many challenges (Figure 1). The lack of genuine cross-border partnerships (55.4\%), lack of adequate financial support $(42.6 \%)$ and differences in legislation and regulations $(38.3 \%)$ are the biggest obstacles, followed by the adaptation of production / products (23.3\%), language barriers $(20.7 \%)$ and cultural differences $(32.4 \%)$. Internationalization is difficult, but necessary to overcome the biggest business challenges of start-ups. Profitability (86.2\%) and cash flow (72.3\%) (see Figure 1) are considered by most start-ups to be their biggest challenges and they are usually addressed by expanding the activities of start-ups. Switching to another market means access to a larger number of potential customers, a larger group of people to recruit from and, often, new capital markets, to address additional funding.

The financing sources for growth and expansion, international or not, are often different, not so much in their variety but in frequency of use, compared to already established firms or young firms, but not necessarily innovative. The traditional ways - the personal savings of the founders $(77.8 \%)$ or the support of family and friends $(30.2 \%)$ are the most frequently invoked, but they are followed by business angels $(29.0 \%)$, venture capital $26.3 \%$ ) or various capital investors $(21 \%)$, government grants / financing $(20 \%)$, crowdfunding $(18 \%)$. This order differs from that of regular SMEs which are counting for financing for personal savings, support from family and friends, own sources and bank loans in most cases. To the extent that they can be set up, start-ups also use internal sources (e.g. undistributed profit, active sales, depreciation, by $15.7 \%$ ), bank loans $(7.4 \%)$ or other sources $(4.8 \%)$.

Another way to overcome challenges and to access new opportunities can be through collaboration with other businesses. According to the results of the initial survey, $29 \%$ of start-ups collaborate with large companies and corporations, $41 \%$ with consolidated SMEs, $10 \%$ with universities, $9.5 \%$ with other start-ups, $8 \%$ with government agencies and $3.5 \%$ with NGOs and other entities (Bormans, et al., 2020). Thus, $27 \%$ of the start-ups participating in the survey are engaged in active collaborations with very large corporations, and $68 \%$ of these collaborations are cross-border. Among the various reasons for collaboration are image transfer and reputation (42\%), but especially access to new customers and new markets (83.8\% of participants). In the initial phases, collaboration between SMEs is almost three times more frequent $(79 \%)$ than collaboration with large corporations, $60 \%$ of these collaborations being cross-border (Steigertahl \& Mauer, 2018).

\subsection{Romanian SMEs and start-ups face to expanding on new markets and internationalization}

Regarding the field of Internationalization of SMEs, based on the latest available data, Romania performs in accordance with the EU average in this regard. Although Romania has one of the lowest scores in the EU for SMEs that are exporting online and outside the EU and for SMEs exporting goods outside the EU, Romania performs substantially above the EU average in terms of procedures and formalities prior to import-export operations (European Commission, 2019a).

Moreover, The World Bank's Doing Business Romania 2020 Report shows that Romania has, out of all 10 chapters, the maximum performance (100) and rank 1, at Trading across Borders, as follows: 
Table 1. Main indicators for Romania for the criterion "Trading across Border" in Doing Business 2020 Romania Report

\begin{tabular}{|c|c|c|c|c|}
\hline 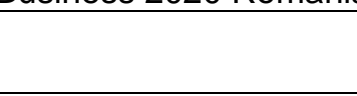 & Romania & $\begin{array}{c}\text { Europe \& } \\
\text { Central Asia }\end{array}$ & $\begin{array}{l}\text { OECD high } \\
\text { income }\end{array}$ & $\begin{array}{c}\text { Best Regulatory } \\
\text { Performance }\end{array}$ \\
\hline \multicolumn{5}{|l|}{$\begin{array}{l}\text { Time \& cost to } \\
\text { export: }\end{array}$} \\
\hline Border compliance $(\mathrm{h})$ & 0 & 16.1 & 12.7 & 1 (19 Economies) \\
\hline $\begin{array}{l}\text { Documentary } \\
\text { compliance (h) }\end{array}$ & 1 & 25.10 & 2.30 & 1 (26 Economies) \\
\hline $\begin{array}{l}\text { Border compliance } \\
\text { (USD) }\end{array}$ & 0 & 150 & 136.8 & 1 (19 Economies) \\
\hline $\begin{array}{l}\text { Documentary } \\
\text { compliance (USD) }\end{array}$ & 0 & 87.60 & 33.40 & 0 (20 Economies) \\
\hline \multicolumn{5}{|l|}{$\begin{array}{l}\text { Time \& cost to } \\
\text { import: }\end{array}$} \\
\hline Border compliance (h) & 0 & 20.40 & 8.50 & 1 (25 Economies) \\
\hline $\begin{array}{l}\text { Documentary } \\
\text { compliance }(\mathrm{h})\end{array}$ & 1 & 23.40 & 3.40 & 1 (30 Economies) \\
\hline $\begin{array}{l}\text { Border compliance } \\
\text { (USD) }\end{array}$ & 0 & 158.80 & 98.10 & 0 (28 Economies) \\
\hline $\begin{array}{l}\text { Documentary } \\
\text { compliance (USD) }\end{array}$ & 0 & 85.90 & 23.50 & 0 (30 Economies) \\
\hline
\end{tabular}

Source: Word Bank Group, Doing Business 2020 Romania (2020, pp. 50-54)

In recent years, Romania has made limited progress in policies and economic measures to support SMEs in this field, only a few implemented programs providing financial and information support to SMEs that help them to internationalize, i.e. to do business abroad, the establishment single access points for information on rules and regulations in foreign markets.

Regarding start-ups, official statistics (INSSE, Eurostat, etc.) are very poor in highlighting aspects of internationalization. The most suggestive data and with a reasonable degree of certainty, can be retrieved survey-based researches conducted by reputable bodies and entities. Although the primary value of this information is certain, it also has a number of drawbacks - as a rule, they do not have a certain repetitiveness over time, which would allow evolving analysis of certain indicators or phenomena; the objectives of the research are different and, as such, the data presented are difficult to compare, or have a conjunctural character, determined by tracking the effects of a particular event or program, and the results may be distorted by the particular criteria and objectives of the research. In the following, we will use mainly three data sources: (1) European Commission Startup Monitor Project 2019 (Bormans, et al., 2020), (2) Ernst \& Young Study (2019) - Business Barometer start-ups in Romania, and, respectively (3) The research conducted by the National Council of Small and Medium Private Enterprises in Romania (CNIPMMR) and the Romanian Commercial Bank (BCR) on the beneficiaries of the 2017 edition of the Start-up Nation program Entrepreneur profile Start-Up Nation (2019).

According to the European Start-up Monitor (Bormans, et al., 2020), (European Commission, 2019a), Romanian start-ups have a low degree of internationalization, most of these businesses addressing with their products or services the local market, more precisely targeting the consumers in the communities where the start-up carries out its activity (36\%). For the national market, an approximately equal percentage $(34 \%)$ of start-ups offer products and services, and only a third of the businesses at the beginning went abroad, $10 \%$ 
of the total going to the regional market and about $20 \%$ reaching global markets (European Commission, 2019a).

As future plans for their business (Figure 2), the majority of respondents in the EY study (Ernst \& Young Global Limited, 2019) are considering expanding their business to another area $(65 \%)$. Regarding a possible expansion abroad intended in the short or long term, a third of the surveyed entrepreneurs affirm their intention to expand abroad $(28 \%)$, but most of them $(45 \%)$ do not consider this strategy for the future. According to them, one third of entrepreneurs do not have a clear image of what they will do in the future in terms of exit strategy, their limited experience in entrepreneurship being one of the reasons (Ernst \& Young Global Limited, 2019).

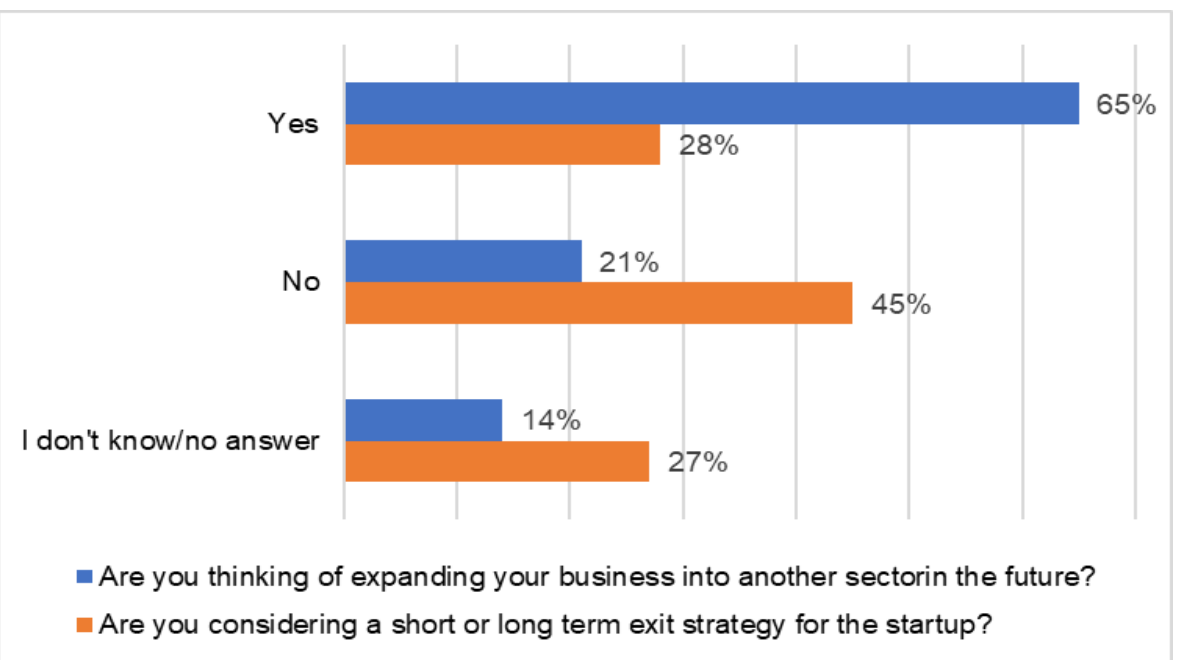

Figure 2. Strategies of expansion or exit, on short term or long term, in the case of start-ups Source: (Ernst \& Young Global Limited, 2019)

As part of future plans to expand into new, internal or external markets, entrepreneurs at the beginning of the road plan to access new external markets in a proportion of about $50 \%$. The most mentioned area of expansion is the regional one, Europe, which is targeted by $51 \%$ of those who want to enter new geographic markets. A very large number of start-ups want to enter the American market (17\%). A relatively small proportion of such companies $(10 \%)$ are thinking of expanding nationally in other cities in Romania that they have not accessed so far (Ernst \& Young Global Limited, 2019), see Table 2.

Table 2. If you plan to expand into new internal or international markets, which would be the markets targeted?

\begin{tabular}{|c|l|c|c|}
\hline Internal & Romania (10\%) & \multicolumn{2}{|c|}{} \\
\hline \multirow{5}{*}{ International } & \multirow{2}{*}{ Europe (51\%), from which: } & Germany & $7 \%$ \\
\cline { 2 - 4 } & & Bulgaria & $3 \%$ \\
\cline { 2 - 4 } & Asia (5\%), from which: & Hungary & $1 \%$ \\
\cline { 2 - 4 } & $\begin{array}{l}\text { America de Nord (18\%), from } \\
\text { which: }\end{array}$ & China & $2 \%$ \\
\cline { 2 - 4 } & Africa (1\%) & Canada & $17 \%$ \\
\cline { 2 - 4 } & Global (3\%) & \multicolumn{2}{|c}{} \\
\hline
\end{tabular}

Source: (Ernst \& Young Global Limited, 2019) 
Start-ups are vulnerable and depend on a number of interdependent resources that work together to support themselves in the development stages. The biggest obstacles that startup entrepreneurs face in 2019 are related to the lack of capital for investments (45\%), the limited promotion budget (38\%), but also the need for new customers they do not know where to find (34\%). The insufficient qualified personnel is also a serious challenge faced by an important part of Romanian start-ups (35\%) and which makes their development difficult.

Completing the above, the CNIPMMR study, starting from the fact that the financing offered can fuel the long-term development plans of the start-ups, intended to examine the potential of the companies financed by the Start-Up Nation program in internationalization area. (National Council of Private Small and Medium Enterprises in Romania (CNIPMMR), 2019a). The results indicate that just over a third (37\%) of businesses consider that they have such potential, the rest either do not know if internationalization is a possible option $(38 \%)$ or believe that they do not have the potential to internationalize the business $(25 \%)$, at least at the time of the study.

\section{Conclusion}

In this paper we intended to explain and conceptualize start-ups by focusing on the problems and specificities of their life cycle. Our approach was to review the main theories on startups and the main challenges they may face at the beginning of the road, admitting that more careful research is needed on the stages of growth and challenges coming from various areas of the economic and social environment. However, growth is a crucial part in the orientation of start-ups and a large part of start-ups aim to grow rapidly, to expand into new markets, including through internationalization. By employing mostly studies based on surveys at EU and Romania level, we captured the special appetite of EU start-ups to capitalize on the advantages of the European single market and, hence, to prepare the conditions for real internationalization, on markets outside the EU, despite considerable difficulties and challenges. Regarding Romanian start-ups, we found out that they are constrained by additional challenges, internal or external. Although Romania is performing very well in terms of the legislative and organizational framework for trading across borders, there are a number of other issues that hinder access to the European single market and, even more so, in internationalization outside the EU. Probably this is an explanation of the fact that at most $50 \%$ (or even less) of Romanian companies believe that they have potential and want to expand in foreign markets (probably even fewer really do), compared to over $80 \%$ at the level European. The lack of training, the limited innovative character of the Romanian products, the competition and the lack of an authentic financial support make the Romanian entrepreneurs at the beginning of the road to be cautious in the option of internationalization. Of course, these are the first premises of our research, and therefore we intend to analyse in more depth in the second part of this research the relationship between the evolution of start-ups and the main indicators of internationalization, as shown by statistics and reports of European and international bodies.

\section{References}

Adizes, I., 1989. Corporate Lifecycles: How and Why Corporations grow and die and what to do about it. Englewood Cliffss, N.J.: Prentice Hall.

Badulescu, D., 2013. Dezvoltarea și finanțarea afacerilor antreprenoriale. Particularități în turism/Development and financing of entrepreneurial business. Particularities in tourism. Cluj Napoca, Romania: Presa Universitară Clujeană. 
Badulescu, D. \& Badulescu, A., 2014. Antreprenoriatul. Cum, cine, când?. Cluj Napoca, Romania: Editura Presa Universitară Clujeană.

Bhave, M., 1994. A process model of entrepreneurial venture creation. Journal of Business Venturing, 9(3), pp. 223-242. https://doi.org/10.1016/0883-9026(94)90031-0

Block, Z. \& MacMillan, I., 1985. Milestones for successful venture planning. Harvard Business Review, 63(5), pp. 184-196.

Bormans, J., Privitera, M., Bogen, E. \& Cooney, T., 2020. European Startup Monitor 2019/2020, s.I.: European Commission, COSME Programme.

Consiliul Național al Întreprinderilor Private Mici și Mijlocii din România (CNIPMMR), $2019 a$.

Profilul antreprenorului Start-Up Nation. [Online] Available at: http://cnipmmr.ro/2019/05/15/profilul-antreprenorului-start-up-nation/_[Accessed $18 \quad 07$ 2020].

Ernst \& Young Global Limited, 2019. Barometrul afacerilor de tip startup din România, s.I.: EY Romania.

European Commission, 2019a. 2019 SBA Fact Sheet. Romania, s.I.: Internal market, industry, entrepreneurship and SMEs.

Galbraith, J., 1982. The stages of growth. Journal of Business Strategy, 3(4), pp. 70-79. https://doi.org/10.1108/eb038958.

Gartner, W., 1985. A conceptual framework for describing the phenomenon of new venture creation. Academy of Management Review, 10(4), pp. 694-706. https://doi.org/10.5465/amr.1985.4279094.

Greiner, L., 1972. Evolution and revolution as organization grow. Harvard Business Review, 50(4), pp. 37-47.

Hanks, S. \& Watson, C., 1993. Tightening the life-cycle construct: A taxonomic study of growth stage configurations in high-technology organizations. Entrepreneurship Theory and Practice, 18(2), pp. 5-29. https://doi.org/10.1177\%2F104225879401800201.

Hannan, M. \& Freeman, J., 1977. The Population Ecology of Organizations. American Journal of Sociology, 82(5), pp. 929-964.

Kaiser, U. \& Müller, B., 2013. Team heterogeneity in startups and its development over time, s.I.: ZEW-Centre for European Economic Research Discussion Paper, (13-058).

Kamps, J. \& Pólos, L., 1999. Reducing Uncertainty: A Formal Theory of Organizations in Action. American Journal of Sociology, 104(6), pp. 1776-1812. https://doi.org/10.1086/210223.

Katz, J. \& Gartner, W., 1988. Properties of Emerging Organisation. Academy of Management Review, Volume 13, pp. 429-441. https://doi.org/10.2307/258090.

Kaulio, M., 2003. Initial conditions or process of development? Critical incidents in the early stages of new ventures. R\&D Management, 33(2), pp. 165-175. https://doi.org/10.1111/1467-9310.00290.

Kazanjian, R., 1988. Relation of dominant problems to stages of growth in technology based new ventures. Academy of Management Journal, 31(2), pp. 257-279. https://doi.org/10.5465/256548.

Lim, S., Platts, K. \& Minshall, T., 2008. An exploratory study on manufacturing strategy formulation in start-up companies. Enschede, The Netherlands, 16th High Technology Small Firms Conference, January 2008.

Miles, R. \& Rosenberg, H., 1983. The human resources approach to management: Secondgeneration issues. Organizational Dynamics, 10(3), pp. 26-41. https://doi.org/10.1016/00902616(82)90034-1.

Miller, D., 2000. Organizational configurations: Cohesion, change, and prediction. Human Relations, 43(8), pp. 771-789. https://doi.org/10.1177\%2F001872679004300805.

Pettigrew, A., Thomas, H. \& Whittington, R., 2001. Handbook of Strategy and Management. Sage Publication: USA. 
Ritchie, J. \& Richardson, S., 2000. Smaller business governance: exploring accountability and enterprise from the margins. Management Accounting Research, 11(4), pp. 451-474. https://doi.org/10.1006/mare.2000.0144.

Rogers, S., 2009. Entrepreneurial Finance. Finance and Business Strategies for the Serious Entrepreneur. Second Edition ed. New York: McGraw-Hill Companies.

Salamzadeh, A., 2015. New Venture Creation: Controversial Perspectives and Theories. Economic Analysis, 48(3/4), pp. 101-109.

Scholz, M. \& Reydon, T., 2009. Organizational Ecology: No Darwinian Evolution After All. A Rejoinder to Lemos. Philosophy of the Social Sciences, 40(3), p. 504-512. https://doi.org/10.1177\%2F0048393109348866.

Schumpeter, J., 1934. The theory of economic development: An inquiry into profits, capital, credit, interest, and the business cycle (Vol. 55). s.l.:Transaction publishers.

Slevin, D. \& Covin, J., 1998. Time, growth, complexity, and transitions: Entrepreneurial challenges for the future. Entrepreneurship Theory and Practice, 22(2), pp. 53-68. https://doi.org/10.1177\%2F104225879802200205.

Smith, K., Mitchell, T. \& Summer, C., 1985. Top level management priorities in different stages of organizational life cycle. Academy of Management Journal, 28(4), pp. 799-820.

Steigertahl, L. \& Mauer, R., 2018. https://doi.org/10.5465/256238.

EU Startup Monitor 2018. [Online] Available at: http://startupmonitor.eu/EU-Startup-Monitor2018-Report-WEB.pdf] [Accessed 1203 2020].

Tosi, H. \& Slocum, J., 1984. Contingency theory: Some suggested directions. Journal of Management, 10(1), pp. 9-26. https://doi.org/10.1177\%2F014920638401000103.

Tsai, S. \& Lan, T., 2006. Development of a Startup Business - A Complexity Theory Perspective, Kaohsiung, Taiwan: National Sun Yat-Sen University.

Van de Ven, A., Hudson, R. \& Schroeder, D., 1984. Designing new business startups: Entrepreneurial, organizational, and ecological considerations. Journal of Management, 10(7), pp. 87-108. https://doi.org/10.1177\%2F014920638401000108.

Vesper, K., 1990. New Venture Strategies. 2nd ed. ed. Englewood Cliffs, NJ: Prentice Hall. Word Bank Group, 2020. Doing Business 2020 Romania, Washington, D.C.: World Bank.

\section{Bio-note}

Anamaria Diana Herte graduated at University of Oradea, Faculty of Economic Sciences and now is Ph.D. student at the same university. In her doctoral research she focuses on the Start-ups in the contemporary economy.

Daniel Badulescu graduated at Bucharest University of Economics and currently is Professor and Ph.D. supervisor at the Doctoral School in Economics within the University of Oradea, Romania. 